\title{
Doing Business with Deleuze?
}

Finn Janning

\begin{abstract}
This essay has two parts. The first part gives a brief overview of the foundation of economics. The second part contains a broader outline of the way in which philosopher Gilles Deleuze thinks of ethics. In the second part, I also explore the potential connections between Deleuze's thoughts and economics. Especially, I focus on the concepts of "human capital," "empowerment," and more fruitful, the concept of "power-with" as proposed by organizational theorist, Mary Parker Follett. By doing so, I try to minimize the gap between economics and ethics as presented here. Finally, I determine whether it is possible to do business with Deleuze.
\end{abstract}

Keywords: Deleuze, economics, ethics, power

\section{Introduction}

The French philosopher, Gilles Deleuze, provides an interesting distinction between morals and ethics: the difference between a transcendent set of values or norms and immanent modes of existence. ${ }^{1}$ The first tells us what we must do, whereas the other asks what might be possible. Such an ethical and immanent approach, of course, opens up the much more challenging task of deciding how to act or what to affirm since no predefined norms can guide us. It emphasizes that ethics begins when one needs to make a decision on an uncertain foundation.

Let me propose a simple example: You are a business leader making a decision. However, soon you realize that your personal values interfere

${ }^{1}$ Most notable his immanent ethical thinking is present in the following works: Expressionism in Philosophy: Spinoza, trans. by M. Joughin (Zone Books, 1997); Spinoza: Practical Philosophy, trans. By R. Hurley (City Lights Books, 1988); The Logic of Sense, trans. by M. Lester (Continuum, 2004); and Nietzsche and Philosophy, trans. by H. Tomlinson (Continuum, 2002). Some of the guiding ideas in these works are-how one acts instead of reacts; how one evaluates instead of judge. Deleuze writes, e.g., in Nietzsche and Philosophy: "We always have the beliefs, feelings, and thoughts we deserve, given our way of being or our style of life." Nietzsche and Philosophy, 1 . There is not outside norm to benchmark against.

(c) 2015 Finn Janning

http://www.kritike.org/journal/issue 16/janning june2015.pdf

ISSN 1908-7330

$(c c)$ BY-NC-ND 
with the values of the stakeholders as well as the workforce. It is a dilemma. How do you make a responsible decision?

The difference between morality and ethics is that the former is guided by fixed categories or criterion, for example, whether one needs to focus on the consequences or whether one has a duty to comply with one's stakeholders. The consequences could be related to financial outcome, image and brand value, the number of future clients or partners, etc. Similar, duties could refer to what Boxall and Purcell call "best fit," for instance, the organization's duty to adapt the norms and ideals of the society or the industry. The point is, according to Boxall and Purcell, that the business should be shaped according to the norms and ideals of the context, at least, if the business is to avoid losing strategic advantages. ${ }^{2}$

In ethics - as Deleuze understands it - no such rules exist. Ethics is, rather, related to one's approach when one cannot step outside the immanent movement of becoming to see whether one's actions fit. In an ethical approach, one attempts to become aware in the sense that the observer and the observed melt together. The point is to see what might be possible or what one can also do. That is to say, not to add perspectives from higher normative positions, but to unfold what is real but yet to be actualized. ${ }^{3}$ Ethics, therefore, is related to the freedom to become what one can, not necessarily what one will become as a practice of being. ${ }^{4}$

My thesis is that the distinction between philosophy and economics is one of freedom. One might call it a difference between existential freedom

2 See P. Boxall and J. Purcell, Strategy and Human Resource Management (Palgrave Macmillan, 2011), 72 cf.

${ }^{3}$ G. Deleuze and F. Guattari, What is Philosophy?, trans. by H. Tomlinson and G. Burchell (Columbia University Press, 1994), on page 156 they write: "real without being actual, ideal without being abstract." This quote emphasizes that another possible world might come into being, because the ideal is not understood as something abstract (or unchangeable); rather, it is related to time as change.

${ }^{4}$ Some of the critical points mentioned here are already articulated in the work of the Frankfurt School critical theorists such as Marcuse, Adorno, and Honneth. For example, Honneth raises a strong critique towards the ideals that guide human behavior in today's competitive society, e.g., the ongoing demand for self-realization that easily can turn into an unhealthy selfobsession. Thus, Honneth is critical towards the spirit of capitalism. However, unlike Deleuze, his position is normative. Honneth criticizes the social pathologies, e.g., when an unhealthy selfobsession leads to stress, depressions, low self-esteem and self-respect, from a healthier position. Deleuze does not operate with a "healthy" norm. Rather his critique is based on an evaluation of what happens here and now, which may or may not cause sad or joyous feelings. In one of Deleuze's last essays, he seems to raise critical questions from what might appear to be a normative position, e.g., when he states: "We're told that businesses have souls, which is surely the most terrifying news in the world." Yet, the problem is not whether the soul of capitalism is good or bad (based on what criteria's?), but to go further. See G. Deleuze, "Postscript on Control Societies," in Negotiations, trans. by M. Joughin (Columbia University Press, 1995), 181. See also A. Honneth, The Struggle for Recognition: Moral Grammar of Social Conflicts, trans. by J. Anderson (Polity Press, 2005).

(c) 2015 Finn Janning

http://www.kritike.org/journal/issue 16/janning june2015.pdf

ISSN 1908-7330

(cc) BY-NC-ND 
and economic freedom. An existential freedom can be seen as a mixture of having the courage to oppose constraining norms and ideals and the creative or imaginative power to establish fruitful relations. The point is not to oppose or plead for another position. Instead freedom is a preposition trying to relate to what might work. ${ }^{5}$ To put it simply: Economic freedom reduces existential freedom to gain profitable advantages. The context is given. Therefore, doing business with Deleuze would basically lead to at least one drastic change, that is, a change where the human being is no longer outside the equation. First, though I will outline a brief understanding of economics, I will then turn to Deleuze to see whether it is possible to do business differently.

\section{Economics}

Economics deals with the production, distribution, and consumption of services and goods on a national, trans-national, and organizational level. ${ }^{6}$ At times, it can be difficult to distinguish these concepts; for example, when one is consuming a product, one is at the same time distributing and producing. For simplicity, think of social media and how reading a blog post can be viewed not only as consumption but also as production (i.e., interpretation) and distribution. When one likes or comments on a blog, one is at the same time consuming, distributing, and adding value to the product.

In a modern business organization, an employee not only produces but also consumes and distributes ideas, different forms of life, culture, knowledge, services, moods, etc. Hence, a growing part of the global workforce is producing immaterial goods and services, such as knowledge, communication, events, happiness, etc. Some theorists talk about "affective labor" or "immaterial labor." 7 The concept is interesting because it emphasizes how "social life itself becomes a productive machine." ${ }^{8}$ It is also interesting because it addresses the main problem of modern business organizations, which is how to avoid limiting or controlling the potential productivity that stems from social life itself.

One question emerges: Does the general business organization acknowledge that the values produced in an organization presuppose the forms of life that support them? A realistic answer is "no." Let me mention

${ }^{5}$ This understanding of freedom, I will show, is also related to the concept of 'powerwith' as defined by M. P. Follett and E. W. Holland. See also F. Janning, "Who lives a life worth living?," Philosophical Papers and Review, 4:1 (2013), 8-16.

${ }^{6}$ See e.g., R. G. Hubbard, R.G. and A.P. O’Brien, Economics (Pearson Education, 2012).

7 See e.g. Michael Hardt \& Antonio Negri, Empire (Harvard University Press, 2001); Maurizio Lazzarato, "Immaterial Labor," in Radical Thought in Italy. A Potential Politics, ed. by P. Viorno \& M. Hardt (University of Minessota Press, 2006).

${ }^{8}$ Michael Hardt \& Antonio Negri, Multitude: War and Democracy in the Age of Empire (Penguin Books, 2005), 148.

(C) 2015 Finn Janning

http://www.kritike.org/journal/issue 16/janning june2015.pdf

ISSN 1908-7330

(c) BY-NC-ND 
one example. The concept of "human capital" emphasizes how the "human" within businesses adds value that can be measured in capital. However, reporting on human capital is not a random measurement; instead, the measurement of the employee must be linked to the overall performance of the business. ${ }^{9}$ A way of measuring employees is the "human capital indicator," which identifies the human value of the enterprise. Such worth is equal to the employment cost multipled by the human asset worth. ${ }^{10}$ The term "human asset worth" refers to capability, potential growth, personal performance, and alignment with the organization's value set. ${ }^{11}$ The point is that capability or growth is of value if it fits into the organizational context. As one researcher says, "Not surprisingly, workers with human capital on average earn more than those with less human capital." 12 In other words, if employees can deliver what they should, then they are valued employees. However, what if they could deliver more? What if the business culture is too narrow in its understanding of growth, capacity and value?

The use of a concept like "human capital" emphasizes that a rational business decision is one guided by the potential economic profit, not, for instance, happiness, joy, or well-being. ${ }^{13}$ Of course, one might simply ask why a business organization, or its leaders, should subordinate the motive of profit for well-being. The almost forgotten management or organizational theorist Mary Parker Follett is worth recalling. She writes: "We all want the richness of life in terms of our deepest desires. We can purify and elevate our desires, we can add to them, but there is no individual or social progress in curtailment of desires." 14 The richness that all human beings desire is, as I read Follett, a good life-a life filled with more moments of happiness than sadness, for example. Another problem with the term "human capital" is the question of what to value even when the context is strictly financial. As some ask, "Should workers' pay depend on how much they work, or on how much they produce?"15 This question asks what the scarce resource is: time or

\footnotetext{
${ }^{9}$ M. Armstrong, Armstrong's Handbook of Human Resource Management Practice, $12^{\text {th }}$ edition, (Kogan Page, 2012), 74.

${ }^{10}$ Ibid., 75.

${ }^{11}$ Ibid.

${ }^{12}$ G. N. Mankiw, Principles of Economics (South-Western, 2004), 412-13.

${ }^{13}$ See also Herbert Marcuse, One-Dimensional Man (Routledge, 2002). Marcuse shows how critical reason or resistance has been suppressed by the dominating rationalism of capitalism. The success of capitalism can be seen as how it has seduced the employee to believe that he or she is free. Instead, it has only eliminated dissent by making people content and uncritical. The one-dimensional man is stuck with conformity and, I might add, the predictability of doing business. I would like to thank one of the reviewers for drawing my attention to Marcuse.

${ }^{14}$ M.P. Follett, Dynamic Administration. The Collected Papers of Mary Parker Follett, ed. by H.C. Metcalf \& L. Urwick (Harper \& Brothers, 1940), 145.

${ }^{15}$ Hubbard and O'Brien, Economics, 622.
}

(c) 2015 Finn Janning

http://www.kritike.org/journal/issue 16/janning june2015.pdf

ISSN 1908-7330

(cc) BY-NC-ND 
product. However, how do we distinguish between the time that is used and the product produced? For obvious reasons, it can be difficult to define the time used when we are dealing with intangible or immaterial products such as knowledge, culture, services, etc. How much time does it take to come up with a good idea? Is it one second, or is it the result of months of hard work? How does the organization measure time when employees can work anywhere and anytime?

Economic rationalization orients itself according to the expected revenue. Human capital represents the accumulated training and skills that an employee possesses. Therefore, the logic is that the higher the level of education is, the higher the production will be, which again leads to higher demand for employees with a high level of human capital. Therefore, the general level of education is, apparently, measured with respect to how well it sells or at least produces products that can be sold. In other words, the value of education depends on the output per day. ${ }^{16}$ People like Socrates (who did not even publish a research paper) and the Dalai Lama do not fit into this equation, perhaps because they generate experiences or a space where different experiences can emerge, not necessarily cash flow (even though other people might cash in on their teaching). In other words, perhaps the degree is not really what matters but how an employee approaches things, how he or she thinks, feels and acts. In short: the form of life of the employee.

In addition, one could mention that people with a higher education, unfortunately, also suffer from more stress due to increased pressure from peers as well as social and personal ideals and norms. However, this tendency is normally absent in the theory of economics even though it might tell us that it is the time, not the output per day, that is the scarce resource since high producers tend to burn out before average producers. ${ }^{17}$

This valorization of the economy guides not only our behavior inside a business organization but also what is prestigious, what brings or has status, and how one is recognized. Thus, economics as the guiding tool of measurement affects how we understand freedom. ${ }^{18}$

\footnotetext{
${ }^{16}$ Ibid., 606.

${ }^{17}$ It might also show that the level of intensity plays a crucial role as well as the guiding norms and ideals that indicate what one should do instead of acknowledging what the person can do well. Recent studies in psychology, however, emphasize that, if one is encouraged to do what one does well, it will ignite one's passion so that one is more likely to flourish. See, e.g. M. Chizschentmilahy, Flow: The Psychology of Optimal Experience (Harper Collins, 2007); E. L. Deci and R.M. Ryan, Handbook of Self-Determination Research (The University of Rochester Press, 2002).

${ }^{18}$ I am thinking of the everyday use of terms such as "economic freedom" or "the free market." Similarly, one might find it easier to define concepts such as security, responsibility, trustworthiness, reliability, credibility, etc., by putting the term "economic" in front of each word: economic security, etc. Values, apparently, become valuable only when they can be measured on the bottom line.
}

(C) 2015 Finn Janning

http://www.kritike.org/journal/issue 16/janning june2015.pdf

ISSN 1908-7330

(c) BY-NC-ND 
With this brief overview in mind, I will now focus my attention on Deleuze's engagement with ethics.

\section{Ethics as a Composition of Power}

According to Deleuze, one must resist the dominating norms and ideals in society and try to see oneself as an event, as a body that gradually happens or takes form. ${ }^{19}$ Life ploughs one's body, leaving not only scars and wrinkles but also experiences, knowledge, awareness, etc. For Deleuze, ethics is, as mentioned previously, a typology of immanent modes of existence that replaces morality that always relates existence to transcendent values. ${ }^{20}$ Philosophy, therefore, does not have a political power but an ethical power. An ethical power is a composition of powers, for example, when different forms of life or modes of existence can live side by side, without one being reduced to the other. ${ }^{21}$

Thus, Deleuze might appear arrogant (or naïve) in claiming that philosophy is the only possible ethics. However, it should not be read as a prerogative of doing well. On the contrary, the claim is made because philosophy is an immanent practice that provides space for different forms of life. Ethics is about behavior (ethology) and practice (ethos), but the process of learning, that is to say the form of life, is also a practical behavior. ${ }^{22}$

What, then, does philosophy do? Instead of focusing on what there is, for example, by trying to see what certain organizational movements represent, the philosopher tries to pay attention to what has not yet been actualized but is nevertheless real. This means that stress and burnout are real organizational differences that cause human differences. Such differences are overlooked if we focus only on the same form of expression, such as stress or burnout. What is interesting, therefore, is not curing those who suffer from stress to make the business productive again. Rather, it is coping with the differences or forces that lead to stress. Becoming, in other words, is immanence actualized as practice. The process of becoming is unpredictable; it does not move between fixed states such as healthy and sick. Instead, one tries to understand the change undergone by each employee who suffers from stress. Some helpful questions could be as follows: What is this person

24.

${ }^{19}$ G. Deleuze, The Logic of Sense, trans. by M. Lester with C. Stivale (Continuum, 2004),

${ }^{20}$ G. Deleuze, Spinoza: Practical Philosophy, trans. by R. Hurley (City Lights Books, 1988), 23

${ }^{21} \mathrm{Ibid}$.

${ }^{22}$ Anthony Uhlmann, "Deleuze, Ethics, Ethology, and Art," in Deleuze and Ethics, ed. by Nathan Jun and Daniel W. Smith (Edinburgh University Press, 2011), 154.

(c) 2015 Finn Janning

http://www.kritike.org/journal/issue 16/janning june2015.pdf

ISSN 1908-7330

(cc) BY-NC-ND 


\section{DOING BUSINESS WITH DELEUZE}

absorbing? How does this affect the person's ability to think, to feel, and to act? What overpowers this person's ability to act freely?

Instead of focusing just on workload, time, and energy, one might also notice how norms, ideals, the need for recognition, intensity, pressure, and so forth affect the employee. That is to say, instead of framing what happens to represent certain available solutions, the philosopher becomes interested with what happens and explores solutions that might open up. This is a process where the philosopher allows himself or herself to be affected by forces, perhaps even forces that one is trained to overcome. The process means that the philosopher's relation to the organization changes. The organization is no longer viewed from one position but from multiple positions. In other words, the organization is no longer viewed from its ideal position or set of values but from all positions.

Why is this not happening? The answer is the same as the one Benjamin Franklin once gave: "Remember that time is money." ${ }^{23}$ It is, but time is also what changes us.

A philosophical practice, as outlined here, asks what these symptoms tell us. They tell us that some leaders, for instance, are affirming the wrong things unless the desired output really is stress. The point is not trying to explain why one suffers from stress, or at least one should be cautious about whether an explanation merely refers to a given frame of abstractions. Instead, one constantly tries to actualize what is being formed without neglecting that it can become something else. Literally, one moves around because one's vision depends on one's bodily position. Some guiding questions could be as follows: Are some forms of life being prevented from flourishing? How can these more productive forces be affirmed?

As already shown, the concept of human resource management (HRM) implies that the "resources" are employees. The resources belong to the employer. Therefore, the resources are measured as human capital. This assumption also stresses a relation with classical economic theory through the idea of the "right of ownership." Similarly, it also operates with limited image of what a human being is and what one might be able to do. Performance management, for example, is an ongoing process that ensures that the workforce's activities and output match the goals of the organization. However, it is evident that matching the goals or fitting in does not encourage employees to become self-determined or innovative. Instead, it encourages predictability, perhaps, because predictable employees are easier to manage.

${ }^{23}$ Here quoted from Max Weber, Den protestantiske etik og kapitalismens ånd [The Protestant Ethic and the Spirit of Capitalism], (Nansensgade Antikvariat, 1995), 26. Weber uses Franklin to illustrate how the spirit of capitalism is reducing the meaning of life to a quest for profit.

(c) 2015 Finn Janning

http://www.kritike.org/journal/issue 16/janning june2015.pdf

ISSN 1908-7330

$(\mathrm{Cc}) \overline{\mathrm{BY}-\mathrm{NC}-\mathrm{ND}}$ 
From the perspective of philosophy, the philosopher does not (and cannot) preach about good behavior from a higher and more lucrative position. Philosophy is not a game where the one with the highest ideals wins. Instead of being part of a field or discipline such as HRM, the philosopher is part of life, part of the social practice that no one can control completely. Instead, the philosopher aims at affirming that which works or functions for no other reason. In other words, the affirmation does not serve a purpose but is the purpose. What is worth affirming no one knows beforehand, because no predefined norms can guide us. The possible world is not real-not yet; it exists only in its expression. ${ }^{24}$ The practice is ethical because it is experimental. It is given space for what is in the midst of being expressed, that is, the bliss of action. As Deleuze writes about Spinoza's Ethics, it "is necessarily an ethics of joy: only joy is worthwhile, joy remains, bringing us near to action, and to the bliss of action." ${ }^{25}$ It aims at affirming that life brings joy or forces one to think, because by affirming these forces, this joy, the forces of life will return. ${ }^{26}$ It is an example of a responsible and sustainable ethics since it is passing on what lives. One matches what happens. How does one do that?

\section{Amor Fati}

In What Is Philosophy? Deleuze and Guattari write:

The event is actualized or effectuated whenever it is inserted, willy-nilly, into a state of affairs; but it is counter-effectuated whenever it is abstracted from states of affairs so as to isolate its concept. There is a dignity of the event that has always been inseparable from philosophy as amor fati: being equal to the event, or becoming the offspring of one's own events. ${ }^{27}$

The kind of creation that philosophy effectuates moves from the actual toward the virtual. The virtual is a force that illustrates how a problem always is something that one overcomes by establishing innovative or creative connections that open up new paths. Ethics, at least as presented

${ }^{24}$ Deleuze and Guattari, What is Philosophy?, 17.

${ }^{25}$ Deleuze, Spinoza: Practical Philosophy, 28.

${ }^{26}$ This idea is a spinoff from Nietzsche's 'eternal return' that he defines: 'Do you desire this once more and innumerable times more?', see F. Nietzsche, The Gay Science, trans. by W. Kaufman (Vintage, 1974), 271. Deleuze follows when he writes: 'whatever you will, will it in such a way that you also will its eternal return,' as he writes in Nietzsche and Philosophy, 68.

${ }^{27}$ Deleuze and Guattari, What is Philosophy?, 159. 
here, are not based on being or essence, for instance, that knowledge is to know something about something fixed. 'There is no other ethic than the amor fati of philosophy. ${ }^{28}$ Therefore, the sole purpose of philosophy is to become worthy of the event, that is, what happens while it happens. One might emphasize that amor fati or being worthy of the event easily leads to passive acceptance of what is. It does not. Instead, the point is to relate amor fati to what happens, as well as what might happen. ${ }^{29}$ Philosophy, Deleuze and Guattari write, "does not look for the function of what happens but extracts the event from it." 30 The point is that philosophy does not encourage suffering, for instance, by making room for a moralistic victimization of what happens. Unfortunately, this often happens when transcendent values or norms produce more victimization than a true will to act. For example, instead of feeling sorry for those who suffer from stress or burnout, one simply needs to change the leadership style that maintains or even creates a culture of stress. ${ }^{31}$ Similarly, Deleuze and Guattari try to avoid victimization when they take "complaint and rage to the point that they are turned against what happens so as to set up the event, to isolate it, to extract it in the living concept. Philosophy's sole aim is to become worthy of the event ...."32 Affirm that in life in order to encourage growth. That is to say, see stress or burnout as something healthy, the body's last resistance against what is killing it. ${ }^{33} \mathrm{As}$ Colombat writes, 'life is constituted by all the forces that resist death.' ${ }^{34}$ This ethical approach tries to become the event; that is to say, it acts with it. It composes new meaning, new values from the middle of the event.

It is an affirmative practice that affirms (or repeats) that which brings life to the event or affirms the living in the event. It is a practice that affirms the being of becoming. Too often, we do not notice what is in the midst of becoming because we are guided by expectations, habits of following transcendent norms or values. For example, that a higher is better than a

${ }^{28}$ Ibid., 159.

${ }^{29}$ Levi R. Bryant, "The Ethics of the Event: Deleuze and Ethics without A $\rho \chi \eta$," in Deleuze and Ethics, ed. by Nathan Jun \& Daniel W. Smith (Edinburgh University Press, 2011), 32.

${ }^{30}$ Deleuze and Guattari, What is Philosophy?, 160.

${ }^{31}$ The psychologist Zimbardo has shown how it is leaders (i.e., the system) that maintain or create a culture (i.e., the situation). It is important because it is the culture or situation that affects the individual. In other words, norms, group pressure, roles, obedience, need to belong, etc. make it difficult to uphold personal values without being affected at all by the situation. See P. Zimbardo, The Lucifer Effect: Understanding How Good People Turn Evil (Random House Trade Paperbacks, 2008).

${ }^{32}$ Deleuze and Guattari, What is Philosophy?, 160.

${ }^{33}$ F. Janning, "The Happiness of Burnout," in Journal of Philosophy of Life, 4:1 (2014), 48-

67.

${ }^{34}$ A. P. Colombat, “November 4, 1995: Deleuze`s death as an event," in Man and World, 29 (1996), 245.

(C) 2015 Finn Janning

http://www.kritike.org/journal/issue 16/janning june2015.pdf

ISSN 1908-7330

(cc) BY-NC-ND 
lower level of output per day. Still, one might ask Cervantes if it is better to have written Don Quixote or a list of 100 books that no one can remember afterwards.

Ethical practice-instead of following higher ideals or norms - tries to bring together the forces of an event; that is to say, it makes room for what is coming in the middle of what happens. The ethic of joy, as Deleuze names it, is related to this practice because it emphasizes the joy of being alive and nothing else. These forces are joined in the virtual event of the concept that ties the forces together, pushing it forward. In that sense, the concept is a gesture that carries something or passes something on to the next generation. The force to act is understood here as the will to act and create room for things to grow. Of course, the virtual event of the concept is never fully actualized. One can never fully claim to have actualized the virtual concept of a financial crisis: values, norms, ideals, language, etc. Instead, a philosophical concept tries to safeguard or make room for that which is becoming. It is a generous practice because it aims at sustainability.

\section{Let's all get Rich}

Today, more and more people have the opportunity to create something new due to a general improvement in standards of living and welfare, as well as to technological inventions. However, many people restrain themselves or-more likely - are controlled by the norms and ideals that rule most societies. The will to create, therefore, requires courage. To put it differently, the amor fati that Deleuze and Guattari speak about is both critical and creative. An affirmative practice both stands against the dominating norms and ideals and creates a virtual event where something might become. It is between this courage to resist the habit of following the norms rather than what brings life and the ability to create that existential freedom emerges. An economic freedom, on the other hand, is predictable.

An immanent ethics, as suggested here, is far more risky than being able to refer to a transcendent set of laws or values. Such a transcendent practice is often used within business such as HRM, especially when one tries to motivate by external means instead of intrinsic ones. However, the moral teaching diminishes to some extent when more and more people try to organize their capacities differently when they share knowledge and information, for instance, on the Internet in a way that differentiates itself from a classical zero-sum game. The economy rests upon exchanges that are based on scarcity. One example illustrates this: ${ }^{35}$ If one has 100 euros in one's

\footnotetext{
35 The example is well known, but it came to my attention reading an interview with Michel Serres (1998), Knowledge's Redemption. The interview is available online $<$ http://www.nettime.org/Lists-Archives/nettime-1-9810/msg00137.html>. 
pocket and a friend has nothing, by giving the friend 100 euros, one will end up with nothing. This is an example of a zero-sum game. However, knowledge operates in the opposite fashion. If one knows something and teaches or shares this knowledge with a friend who does not know it, then he or she will know it, but unlike the money in one's pocket, the one who shares it will still know about it as well. This is another way of illustrating that knowledge or wisdom is not a scarce resource. Once one passes on knowledge or ideas, then it is up to the next talented person to do something with it. Still, one might argue that knowledge is a privilege of the few or more commonly that some institutions try to protect knowledge, thereby making it scarce. But hackers, blogs, open universities, open access to research articles, virtual pirates, etc., are resisting the dominance of the traditional press and the illusion of one omnipotent faculty of knowledge, such as universities. No one seems to have the patent on what is really worth knowing. Of course, this development is not without risks or problems. Not only will a lot of the information on the Internet be more or less irrelevant, just as, when one experiments, it opens room for various forces, but some might also be more angry than loving, etc. Still, the point is to be worthy of what happens, to see what it also opens for. That is the challenge. Relying solely on an existing moralistic system does not prevent wrongdoing, but it prevents one from becoming something else.

If we changed the norm from ownership toward borrowing, then maybe we would be more careful about what we pass on. We might all get rich in a way that might not be measured in human capital but nevertheless be worth aiming for. The point being that the values produced are not held in common, that is shared by everyone in the business organization; rather, they are produced in common. Follett writes about democracy that it 'rests on the well-grounded assumption that society is neither a collection of units nor an organism but a network of human relations .... The essence of society is difference, related difference.' ${ }^{36}$ Hence, Follett posits a useful distinction between 'power-with' and 'power-over.' Holland writes: 'Power-with emerges from the articulation of differences each of which contributes positively to a whole that is thereby greater that the merely arithmetic sum of its parts. ${ }^{37}$ Or as Follett herself puts it: 'you have the right over a slave, you have rights with a servant.' ${ }^{38}$ Power-over is for Follett, not a real power, because it hinders the growth of the employee. '[G]enuine power is not

\footnotetext{
36 Here quoted from Eugene W. Holland, "Nomad Citizenship and Global Democracy," in Deleuze and the Social, ed. by Martin Fuglsang and Bent Meier Soerensen (Edinburgh University Press, 2006), 197.

${ }^{37}$ Ibid., 198.

${ }^{38}$ M.P. Follett, Dynamic Administration. The Collected Papers of Mary Parker Follett, ed. by H.C. Metcalf \& L. Urwick (Harper \& Brothers, 1940), 101.

(C) 2015 Finn Janning http://www.kritike.org/journal/issue 16/janning june2015.pdf ISSN 1908-7330
}

(c) BY-NC-ND 
coercive control, but coactive control. Coercive power is the curse of the universe; coactive power, the enrichment and advancement of every human soul.' ${ }^{\prime 3}$ The concept of power-with as well as coactive power highlights a social activity, that is, the strength of participating. ${ }^{40}$

Let me return to HRM. One of the more interesting concepts within HRM in recent years is the concept of "empowerment." Seen from a business perspective, the workforce is free to do whatever is possible within the limits and the logic of economy. Put differently, empowerment allows the employee and organization to respond faster and more flexibly to the demands of the market. ${ }^{41}$ Thus, it is freedom in decision-making within certain limitations, such as the market and the values of the organization.

Seen from a philosophical perspective, "empowerment" is to establish a space for that which is in the process of becoming, even if it appears to go beyond the logic of the economy, such as allowing employees not to do what they want within the framework of the business but to will what they can. This requires both courage and imagination, that is, the courage to allow and encourage true "empowerment," as well as belief in one's ability to nurture what might emerge. The point is that philosophical "empowerment" might open up something that others might benefit from because they are not able to imagine it, such as new knowledge, new ideas, new services, new meaning, etc. It might even be a lack of both courage and creative imagination that has brought the economy to its previous crises. In other words: the economy lacks an affirmative practice that cares solely about that which gives life instead of just repeating the pattern of past successes or trying to fit in for the sake of money.

In other words, the way "empowerment" is used concurs more with "power-over" than "power-with," basically, because it homogenizes the differences of the workforce. Yet, it is not the uniqueness of the employee, which makes him or her of value, but each employee's power to articulate difference that might contribute. ${ }^{42}$

In the final part of this paper, I will return to the concept of freedom to emphasize how a business organization as well as a society is always defined by what it makes possible rather than its differences.

${ }^{39}$ M.P Follett, Creative Experience (Longmans, Green and Co, 1930), xiii.

${ }^{40}$ Here I follow Holland, "Nomad Citizenship and Global Democracy," 198.

${ }^{41}$ B. Dive, The Healthy Organization. A Revolutionary Approach to People E Management (Kogan Page, 2004), 114.

${ }^{42}$ Holland, "Nomad Citizenship and Global Democracy," 197.

(c) 2015 Finn Janning

http://www.kritike.org/journal/issue 16/janning june2015.pdf

ISSN 1908-7330

(cc) BY-NC-ND 


\section{A Life}

Against this background understanding of ethics, morals, and a potential affirmative practice-where the last might be the tool to overcome the dehumanizing element of the economy-I turn to freedom. To explore this concept further, I will say a few additional words about the philosophy of Deleuze and Guattari in What Is Philosophy?

Philosophy is a social practice that, unlike religion or economics, does not refer to transcendent authorities. Instead, philosophical thinking takes places on a plane of immanence. The point is that philosophy creates concepts in a concrete meeting with a non-philosophical field. There is no other world that one can refer to. Philosophy for Deleuze is not a meta-discipline, and it does not refer to a meta-language. This practice means that philosophy does not aim at explaining, reflecting, or representing a higher set of norms or ideals. The plane of immanence changes just as the thoughts change with it.

Now, if we relate this practice to a philosophy about the economy, then the philosophy relates to the economy within the framework or limitations of the economy. Instead, the point in this essay is to enhance the potential liberating thoughts or energies that already take place within an economic system. This is a difference between economic freedom and existential freedom, between relative and absolute freedom. Deleuze and Guattari say that philosophy drives or forces economics' relative change processes to the absolute, that is, to the limit of one's knowledge. It does so by turning it against itself to address 'the coming people,' the one's yet to be expressed. Hereby, it aims at passing life on to the next generation.

In contrast, when HRM believes that human resources belong to the organization, then it not only limits these resources' growth potential (and thereby minimizes their future business potential but, more importantly, it misses the point that the center of attention should not be the human or the resources, even though the former at least would make more sense) but "a life." A life is a multiplicity. For this reason, I have stressed the importance of the articulation of differences, rather than playing a specific role that fits the organizational ideal.

Why, then, is "a life" of importance? Because the way in which one produces new values, new ideas, and new ways of overcoming a problem in other words, how one is innovative and creative-is also part of how one thinks, feels, and acts. Similarly, one's mode of existence is crucial for the values that one might generate. How one thinks, feels, and acts is part of all the actual and potential connections or relations that "a life" already has, as well as those it might create due to its various encounters. It is exactly on the level of encounters that the philosophy of economics is limited; it operates with "best practices," which is why it formulates new future goals based on 
past successes or the best way to "fit in." 43 In other words, economics does not overcome its own inner limits. It is chasing its own shadow. Moving toward a more affirmative practice means staring one's limits straight in the face, extending one's wrinkles around the eyes to the absolute.

The concept of 'the people to come' does not refer to a specific class; as such, it should not be associated with Marxism and class struggle. At least, I do not understand it this way. Rather, 'the people to come' refers to those forms of life, those modes of existence, for which there is no room or space for today. Those people who are neglected or those forms of life that no one listens to. Once again, the affirmative practice does not define its action by means of various contrasts. Instead, by its focus on what might grow because it is growing. "Becoming is always double, and it is the double becoming that constitutes the people to come and the new earth." ${ }^{44}$ An affirmative practice is a continuous process of liberation, that is, becoming. Unlike the classical biblical saying (or claim) that the truth will set one free, an affirmative practice is free to pursue the directions that function in a life regardless of the norms or ideals that one might have to sacrifice. Only a free person will have the courage to follow what he or she must to overcome what is hindering his or her power to enhance a life. Only a free person has the will to create or invent what is needed for this form of life to exist in the future. This, of course, is an ongoing process that, unlike most economics, is in no hurry. A life worth living is not worth rushing. It is to be enjoyed. ${ }^{45}$

${ }^{43}$ Boxall and Purcell, Strategy and Human Resource Management, 73.

${ }^{44}$ Deleuze and Guattari, What is Philosophy?, 109.

${ }^{45}$ It may sound utopian, however, perhaps "utopia is not the best word," as Deleuze and Guattari say in What is Philosophy?, 100. Why do they say that? Thomas More coined the concept utopia in his novel Utopia - where it refers to an Island placed somewhere in an unknown sea. Utopia is the good place that does not exist yet (e.g., the dream of a society that will never be). For this reason, Ernst Bloch says "our epoch has brought with it an 'upgrading' of the utopian - only it is not called this anymore. It is called 'science fiction.' Quoted from I. Buchanan, Deleuzism. A Metacommentary (Edinburgh University Press, 2000), 117). Deleuze and Guattari, as Bloch predicted, actually do refer to another science fiction writer, Samuel Butler and his novel Erewhon. The title Erewhon is an anagram that "refers not only no-where, but also now-here." What is Philosophy?, 100. Instead of seeing utopia as a place, Deleuze and Guattari see it as an approach or process. Hereby they affirm the constant becoming-other, i.e., now and here there is a potential that might be actualized in the creation of a better future. They do not operate with an ideal model, i.e., a perfect utopian island. The "better" future is unknown until it is being created. Deleuze and Guattari suggest that one should connect "with what is real here and now in the struggle against capitalism, relaunching new struggles whenever the earlier one is betrayed" - because of this understanding, they doubt that utopia is the best word. There is, at least for them, no predefined direction to their narrative; instead, it is an ongoing struggle or experimentation (which, I guess, sounds less dreamy). See What is Philosophy?, 100.

(c) 2015 Finn Janning

http://www.kritike.org/journal/issue 16/janning june2015.pdf

ISSN 1908-7330

(cc) BY-NC-ND 


\section{Conclusion}

It seems like the systemic vulnerability of economics is caused by its own unwillingness to risk and experiment with what is yet unknown. This is seen when business organizations favor "best practices" or simply try to "fit in" to what will secure the best return of investment. In addition, it is seen through a concept such as "human resources" and how an organization concordantly evaluates the performance of the employees. Ownership is the end of creativity or innovation. These tendencies (business norms) lead merely to the grim problem of reducing the human to a form of human capital, where the human capacity is reduced to a monetary unit.

As a possible alternative, I suggest (in line with many other thinkers) that one must see each human being as a mode of existence, a life, basically saying that, if a life is not reduced, then this affirmative approach might overcome the manageable simplicity of economics. Here, I refer to the tendency to quantify what cannot be measured beforehand, such as what a life worth living is. Such a life cannot be measured in smiles per day but in general well-being, moments of happiness, and the ability to bring joy to one's life because one actually is allowed to pursue one's power to overcome setbacks in life.

To be empowered within a business organizational frame is to keep everything relative, which is never enough to keep the human being alive and flourishing. Instead, to be empowered philosophically is to overcome struggles in life, which is to live a life on the edge on one's knowledge. It is there on the ridge that one becomes free by resisting the convenient or habitual patterns of repetition, as well as becoming inventive to create possible forms of life that suit one's capacity. The challenge is to will what we can. Such will is both responsible and sustainable because the will shows faith in the future when it creates a culture where a potential becomes actual. It is here that Follett's distinction between 'power-over' and 'power-with' becomes fruitful. The concept 'power-with' emphasizes how the employee is free to express or articulate what he or she can do with the group that he or she encounters.

Thus, doing business with Deleuze means to experiment in order to see what we might be able to do with others. It means constantly questioning what is, which is done by affirming what is in the midst of becoming. Some might object that this does not work in a business organization, that it is too risky, but those people are at the same time saying that "the people" or "a life" is not what counts.

Independent Scholar, Barcelona, Spain

(C) 2015 Finn Janning

http://www.kritike.org/journal/issue 16/janning june2015.pdf

ISSN 1908-7330

(c) BY-NC-ND 


\section{References}

Armstrong, M., Armstrong's Handbook of Human Resource Management Practice, $12^{\text {th }}$ edition, (Kogan Page, 2012).

Boxall, P. and Purcell, J., Strategy and Human Resource Management (Palgrave Macmillan, 2011).

Bryant, L., "The Ethics of the Event: Deleuze and Ethics without A $\rho \chi \eta$," in Deleuze and Ethics, ed. by Nathan Jun \& Daniel W. Smith (Edinburgh University Press, 2011).

Buchanan, I., Deleuzism. A Metacommentary (Edinburgh University Press, 2000).

Chizschentmilahy, M., Flow: The Psychology of Optimal Experience (Harper Collins, 2007).

Colombat, A. P., "November 4, 1995: Deleuze`s death as an event," in Man and World, 29 (1996).

Deci, E. L. and R.M. Ryan, Handbook of Self-Determination Research (The University of Rochester Press, 2002).

Deleuze, G. and Guattari, F., What is Philosophy?, trans. by H. Tomlinson and G. Burchell (Columbia University Press, 1994).

Deleuze, G., "Postscript on Control Societies," in Negotiations, trans. by M. Joughin (Columbia University Press, 1995).

Expressionism in Philosophy: Spinoza, trans. by M. Joughin (Zone Books, 1997).

Nietzsche and Philosophy, trans. by H. Tomlinson (Continuum, 2002).

Spinoza: Practical Philosophy, trans. By R. Hurley (City Lights Books, 1988).

Spinoza: Practical Philosophy, trans. by R. Hurley (City Lights

Books, 1988).

The Logic of Sense, trans. by M. Lester (Continuum, 2004).

The Logic of Sense, trans. by M. Lester with C. Stivale (Continuum, 2004).

Dive, B., The Healthy Organization. A Revolutionary Approach to People \& Management (Kogan Page, 2004).

Follett, M.P., Dynamic Administration. The Collected Papers of Mary Parker Follett, ed. by H.C. Metcalf \& L. Urwick (Harper \& Brothers, 1940). , Dynamic Administration. The Collected Papers of Mary Parker

Follett, ed. by H.C. Metcalf \& L. Urwick (Harper \& Brothers, 1940).

Hardt, M. and Negri, A., Empire (Harvard University Press, 2001).

Multitude: War and Democracy in the Age of Empire (Penguin

Books, 2005).

(c) 2015 Finn Janning

http://www.kritike.org/journal/issue 16/janning june2015.pdf

ISSN 1908-7330

(cc) EY-NC-ND 


\section{DOING BUSINESS WITH DELEUZE}

Holland, E. W., "Nomad Citizenship and Global Democracy," in Deleuze and the Social, ed. by Martin Fuglsang and Bent Meier Soerensen (Edinburgh University Press, 2006).

Honneth, A., The Struggle for Recognition: Moral Grammar of Social Conflicts, trans. by J. Anderson (Polity Press, 2005).

Hubbard, R. G. and O'Brien, A.P., Economics (Pearson Education, 2012).

Janning, F., "The Happiness of Burnout," in Journal of Philosophy of Life, 4:1 (2014)

"Who lives a life worth living?," Philosophical Papers and Review, 4:1 (2013).

Lazzarato, M., "Immaterial Labor," in Radical Thought in Italy. A Potential Politics, ed. by P. Viorno \& M. Hardt (University of Minessota Press, 2006).

Mankiw, G. N., Principles of Economics (South-Western, 2004).

Marcuse, H., One-Dimensional Man (Routledge, 2002).

Nietzsche, F., The Gay Science, trans. by W. Kaufman (Vintage, 1974).

Serres, M., Knowledge's Redemption, (1998), <http://www.nettime.org/ListsArchives/nettime-1-9810/msg00137.html $>$.

Uhlmann, Anthony, "Deleuze, Ethics, Ethology, and Art," in Deleuze and Ethics, ed. by Nathan Jun and Daniel W. Smith (Edinburgh University Press, 2011).

Weber, M., Den protestantiske etik og kapitalismens ånd (Nansensgade Antikvariat, 1995).

Zimbardo, P., The Lucifer Effect: Understanding How Good People Turn Evil (Random House Trade Paperbacks, 2008).

(c) 2015 Finn Janning

http://www.kritike.org/journal/issue 16/janning june2015.pdf

ISSN 1908-7330

(c) ) BY-NC-ND 